$\xi=-1$

\title{
Biogas Production from Combined Irish Potato and Poultry Wastes: Optimization and Kinetic Studies
}

\author{
Umar M. Ibrahim ${ }^{1}$, Saeed I. Ahmed ${ }^{1 *}$, Babagana Gutti' ${ }^{2}$, Idris M. Muhammad ${ }^{1}$, Usman D. Hamza ${ }^{1}$ and \\ Mustapha D. Ibrahim ${ }^{1}$
}

${ }^{1}$ Department of Chemical Engineering, Abubakar Tafawa Balewa University, Bauchi, Nigeria

${ }^{2}$ Department of Chemical Engineering, University of Maiduguri, Maiduguri, Nigeria

*Corresponding Author Email: alsaeedng@yahoo.com

\begin{abstract}
The combination of Irish potato waste (IPW) and poultry waste (PW) can form a synergy resulting into an effective substrate for a better biogas production due to some materials they contain. In this work, optimization and kinetic study of biogas production from anaerobic digestion of IPW and PW was investigated. Response surface methodology (RSM) was applied to optimize conditions such as initial pH, solids concentrations and waste ratios. The anaerobic digestion of the two wastes was carried out in the mesophilic condition and BoxBehnken design (BBD) was used to develop and analyze a predictive model which describes the biogas yield. The results revealed that there is a good fit between the experimental and the predicted biogas yield as revealed by the coefficient of determination (R2) value of $97.93 \%$. Optimization using quadratic RSM predicts biogas yield of $19.75 \%$ at the optimal conditions of initial $\mathrm{pH}$ value 7.28 , solids concentration (w/v) 9.85\% and waste ratio (IPW:PW) 45:55\%. The reaction was observed to have followed a first order kinetics having R2 and relative squared error (RSE) values of 90.61 and 9.63\% respectively. Kinetic parameters, such as rate constant and half-life of the biogas yield were evaluated at optimum conditions to be 0.0392 day- 1 and 17.68 days respectively. The optimum conditions and kinetic parameters generated from this research can be used to design real bio-digesters, monitor substrate concentrations, simulate biochemical processes and predict performance of bio-digesters using IPW and PW as substrate.
\end{abstract}

Keywords: Anaerobic digestion; Irish potato waste; Kinetic; Optimization, Poultry waste.

\section{Introduction}

Nigeria generates waste at the rate of $0.43 \mathrm{~kg}$ per person per day and the waste contains 60 to 80 percent of biodegradable wastes [1] \& [2]. It has been estimated that Nigeria produces about 1502 $\mathrm{kg}$ of food wastes and 227500 tons of fresh animal waste daily, much of which are not effectively utilized [3] \& [4]. Wastes pose serious environmental and health problems, promote insect vectors like mosquitoes and flies, rats and mice, cause fire hazards, flooding of streams, development of aquatic weeds, odour problems, nuisance, and so on. Some activities at potato industries generate wastes which includes rotten potatoes, potato skins and tubers, those with defects due to mechanical damages and are therefore rejected. These residues have a high perishability and their quick removal and disposal is therefore mandatory, with consequent high costs [5]. Since these materials have high moisture content, they are an eligible feedstock for anaerobic digestion (AD) [6]. The most promising alternative to incinerating, composting and landfilling of these wastes is to digest its organic matter using $\mathrm{AD}$ [7] \& [8]. AD is a biological process that takes place naturally when microorganisms break down organic matter in the absence of oxygen. The main advantage of this process is the production of biogas, which can be used to produce electricity [9]. A valuable effluent called digestate is also obtained, which eventually can be used as an excellent soil condi-tioner (biofertilizer) after minor treatments [9]. Biogas is seen as an important source of energy to meet the electricity de-mands for small towns and rural areas [10]. Biogas is produced by $\mathrm{AD}$ of organic feedstock, the most common being ani-mal wastes and crop residues, dedicated energy crops, domestic food waste and municipal solid waste (MSW) [9] \& [11].

Anaerobic digestion of wastes is suitable for greenhouse gases (GHGs) mitigation and waste management practices and the benefits are the production of biogas for cooking, heating, lighting and electricity generation and the production of bio-fertilizer for agricultural land application. The use of Irish potato waste (IPW) and poultry waste (PW) as raw materials for biogas and bio-fertilizer production will reduce the volume of wastes dumped in solid waste disposal sites (SWDs) and the odour emanating from the poultry farms respectively. There have been many previous studies on the optimization and kinetics of biogas production from anaerobic digestion of agricultural slurries and energy crops or organic wastes [12], [13], [14], [15] \& [16]. However, there are publications on the optimization and kinetics of biogas production from anaerobic digestion of IPW and PW is scarce. There is therefore the need to fill this research gap as the literature on the subject matter is scarce.

Process optimization and kinetic study of biogas production from biodegradable wastes will assist to improve the anaerobic digestion process for industrial application.

Therefore, the aim of this research work is to carry out process optimization and kinetics study of biogas production from anaerobic digestion of Irish potato and poultry wastes. The kinetics parameter generated from this research can be used to size biodigesters, monitor substrate concentration, simulate biochemical processes and predict bio-digesters performance. 


\section{Methodology}

\subsection{Experimental design and fabrication of bio- digesters}

This section explains the factors, levels, range of values and number of runs needed for the optimization using RSM. RSM is a package containing Box-Behnken Design.

The number of experimental runs $(\mathrm{N})$ for the Box-Behnken design (BBD) which is in three levels was calculated using (1) [12].

$$
\mathrm{N}=2 \mathrm{k}(\mathrm{k}-1)+\mathrm{cp}
$$

Where; $\mathrm{k}$ is the number of factors and $\mathrm{cp}$ is the number of centre points.

The factors that affect biogas production process such as initial $\mathrm{pH}$, solids concentration, waste ratio and the range of values were obtained from [6], [13] \& [17]. Table 1 presents factors, levels and range of values for the experimental plan.

Table 1: Levels of Factors and Codes used for Optimization

\begin{tabular}{cccc}
\hline & \multicolumn{3}{c}{ Level and code } \\
\cline { 2 - 4 } Factor & -1 & 0 & 1 \\
\hline Initial pH value, A & 6 & 7 & 8 \\
Solids concentration (w/v), B (\%) & 5 & 10 & 15 \\
Waste ratio (IPW:PW), C (\%) & $0: 100$ & $50: 50$ & $100: 0$ \\
\hline
\end{tabular}

Fifteen (15) anaerobic bio-digesters was determined by (1) and therefore fabricated for the anaerobic digestion of IPW and PW. The bio-digesters were equipped with a digestion chamber, slurry inlet from the top cover, thermometer fixed at the top cover of the bio-digesters, biogas outlet from the top cover and tap head for sampling. The total volume of each bio-digester was $4.63 \mathrm{~L}$ with a working volume of $3.70 \mathrm{~L}$ and gas storage bag of $2.00 \mathrm{~L} \mathrm{[13],} \mathrm{[18],}$ [19] \& [20]. Furthermore, the temperature of the bio-digester content was monitored using thermometer with temperature ranges between $0-100^{\circ} \mathrm{C}$.

\subsection{Preparation of solutions and biogas production}

The preparation of slurry of IPW and $\mathrm{PW}, \mathrm{HCl}$ and $\mathrm{NaOH}$ used for this study were in accordance with the standard methods for the preparation of solutions. The solids concentration of the slurry was evaluated using (2) [13] \& [17].

Solids concentration $=\frac{\text { Mass of dried solids }}{\text { Volume of distilled water }} \times 100 \%(2)$

The slurry was prepared to have solid concentrations (w/v) of $5 \%$, $10 \%$ and $15 \%$. The initial $\mathrm{pH}$ values of the slurry were adjusted to 6,7 and 8 using 5 mol.dm-3 $\mathrm{HCl}$ and $\mathrm{NaOH}$ solutions in accordance with the experimental design.

The biogas production from anaerobic digestion of IPW and PW were carried out under ambient temperature in batch bio-digesters. Stirring of the slurry was done in the afternoon for 1 minute and the temperature of the bio-digesters were monitored daily. Retention time for the anaerobic digestion was 35 days [6] \& [18]. The biogas yield (Y) was evaluated using (3).

$$
\text { Biogas yield, } \mathrm{Y}=\frac{\text { Massof biogas produced }}{\text { Massof slurry }} \times 100 \%
$$

\subsection{Regression, optimization and verification experi- ment}

A second order polynomial model was fitted to the experimental results and the regression model was calculated by analyzing the analysis of variance (ANOVA), p-value and F-value. The adequacy of the model was expressed by the coefficient of determination (R2). The model describes the interaction among the parameters influencing the biogas yield by varying them concurrently. The biogas yield (Y) was modelled using (4).

$\mathrm{Y}=\beta_{0}+\beta_{1} \mathrm{~A}+\beta_{2} \mathrm{~B}+\beta_{3} \mathrm{C}+\beta_{12} \mathrm{AB}+\beta_{13} \mathrm{AC}+\beta_{23} \mathrm{BC}+\beta_{11} \mathrm{~A}^{2}+\beta_{22} \mathrm{~B}^{2}+\beta_{33} \mathrm{C}^{2}$

Where; $\mathrm{A}, \mathrm{B}$ and $\mathrm{C}$ are independent variables upon which $\mathrm{Y}$ is dependent, $\beta 0$ is the constant term, $\beta 1, \beta 2$ and $\beta 3$ are the linear coefficients, $\beta 12, \beta 13$ and $\beta 23$ are interaction coefficients and $\beta 11$, $\beta 22$ and $\beta 33$ are the quadratic coefficients.

Optimization of biogas yield was carried out using RSM. The optimum values of the process variables and the biogas yield were predicted by the statistical software Design Expert 7.0.0 software. The optimum conditions were used for the verification experiment to confirm the model developed; this was used to carry out the kinetic study of the process.

\subsection{Kinetic study}

The concentration of the IPW and PW in the slurry contained in the anaerobic bio-digesters were determined based on the chemical oxygen demand (COD) reduction throughout the duration of the verification experiment. The COD of the slurry was calculated using (5).

$$
\operatorname{COD}\left(\frac{\mathrm{mg}}{\mathrm{L}}\right)=\frac{(a-b) \times f}{v}
$$

Where; $a$ is potassium permanganate $\left(\mathrm{KMnO}_{4}\right)$ consumption by sample (in $\mathrm{mL}$ ), $b$ is $\mathrm{KMnO}_{4}$ consumption by blank sample (in $\mathrm{mL}), f$ is titration factor of the $\mathrm{KMnO}_{4}$ solution and $v$ is the volume of sample (in $\mathrm{mL}$ ). The experimental data obtained from the bio-digesters were checked for fitness using integrated form and half-life models as shown in Table 2.
Table 2: Kinetic Models and Half-Life for different Order of Reactions

\begin{tabular}{cccc}
$\begin{array}{l}\text { Order } \\
\text { reaction } \\
\text { (n) }\end{array}$ & Kinetic model & Integrated form & Half-life $\left(\mathrm{t}_{1 / 2}\right)$ \\
\hline 0 & $\mathrm{r}=\left(\frac{\mathrm{dS}}{\mathrm{dt}}\right)=\mathrm{k}$ & $\mathrm{S}_{\mathrm{t}}=\mathrm{S}_{\mathrm{o}}-\mathrm{kt}$ & $\mathrm{t}_{1 / 2}=\left(\frac{1}{2 \mathrm{k}}\right) \mathrm{S}_{\mathrm{o}}$ \\
1 & $\mathrm{r}=\left(\frac{\mathrm{dS}}{\mathrm{dt}}\right)=\mathrm{kS}$ & $\ln \left(\mathrm{S}_{\mathrm{t}}\right)=\ln \left(\mathrm{S}_{\mathrm{o}}\right)-\mathrm{kt}$ & $\mathrm{t}_{1 / 2}=\left(\frac{\ln (2)}{\mathrm{k}}\right)$ \\
2 & $\mathrm{r}=\left(\frac{\mathrm{dS}}{\mathrm{dt}}\right)=\mathrm{kS}^{2}$ & $\mathrm{~S}_{\mathrm{t}}^{-1}=\mathrm{S}_{\mathrm{o}}^{-1}+\mathrm{kt}$ & $\mathrm{t}_{1 / 2}=\left(\frac{1}{\mathrm{kS}_{\mathrm{o}}}\right)$ \\
\hline
\end{tabular}

$\mathrm{r}$ - rate of reaction, $S_{\mathrm{t}}$ - effluent concentration of slurry, $\mathrm{S}_{\mathrm{o}}$ - influent concentration of slurry, dS - change in $\mathrm{S}, \mathrm{t}$ - time, change in $\mathrm{t}$ and $\mathrm{k}$ - rate constant

The zero, first and second order kinetic models were tested for the residual substrate concentration reduction with time. The kinetic parameters for the reaction were determined by plotting suitable graphs and calculating the slope and the intercept using excel package. The kinetic model with the highest value of coefficient of determination $\left(\mathrm{R}^{2}\right)$ and lowest relative squared error (RSE) describes the model best.

The units of rate constants for the zero, first and second order kinetic models can be evaluated using (6).

Rate constant $(\mathrm{k})=(\text { concentration of slurry })^{1-\mathrm{n}}(\text { time })^{-1}$ 
The RSE was used to compare the zero, first and second order models whose errors are measured in different units. The RSE of the models were evaluated using (7).

$$
\text { Relative squared error }(\mathrm{RSE})=\frac{\sum_{i=1}^{n}\left(p_{\mathrm{i}}-a_{\mathrm{i}}\right)^{2}}{\sum_{i=1}^{n}\left(\bar{a}-a_{\mathrm{i}}\right)^{2}} \times 100 \%
$$

Where; $a$ is the actual value, $p$ is the predicted value and $\bar{a}$ is the mean of actual value.

\section{Result and Discussions}

\subsection{Characterization of Irish Potato and Poultry Wastes}

The results of the characterization of IPW and PW are presented in Tables 3 and 4.

Table 3: Proximate Analysis of IPW and PW

\begin{tabular}{cccccc}
\hline Sample & $\mathrm{pH}$ & $\mathrm{MC}(\%)$ & $\mathrm{TS}(\%)$ & $\mathrm{VS}(\%)$ & $\mathrm{FS} \mathrm{( \% )}$ \\
\hline $\mathrm{A}(100 \%$ IPW) & 6.00 & 13.80 & 86.20 & 63.34 & 36.66 \\
B (100\% PW) & 8.80 & 22.30 & 77.70 & 73.87 & 26.13 \\
C (50\% IPW+50\% & 7.40 & 13.70 & 86.30 & 63.38 & 36.62 \\
PW) & & & &
\end{tabular}

MC - Moisture content, TS - Total solids, VS - Volatile solids, FS - Fixed solids,

IPW - Irish potato waste and PW - Poultry waste.

Table 4: Ultimate Analysis of IPW and PW

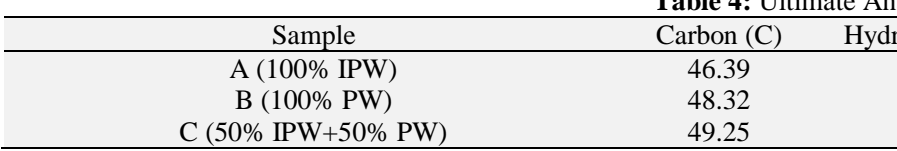

\begin{tabular}{|c|c|c|c|c|c|c|}
\hline drogen & & Nitrogen & (N) & Ir $(\mathrm{S})$ & Oxygen $(\mathrm{O})$ & $\mathrm{C} / \mathrm{N}$ ratio \\
\hline 7.68 & & 1.30 & & & 44.44 & $35.57: 1$ \\
\hline 6.29 & & 2.28 & & & 42.83 & $21.15: 1$ \\
\hline 7.14 & & 1.52 & & & 41.92 & $32.43: 1$ \\
\hline d & $\mathrm{n}$ & $\begin{array}{c}\text { Ini- } \\
\text { tial } \\
\mathrm{pH} \\
\text { value }\end{array}$ & $\begin{array}{l}\text { concentra- } \\
\text { tion }(\%)\end{array}$ & $\begin{array}{c}\text { ratio } \\
\text { (IPW:P } \\
\text { W) }(\%)\end{array}$ & mental (\%) & ed $(\%)$ \\
\hline 1 & 3 & 6 & 5 & 50 & 16.26 & 15.85 \\
\hline 2 & 6 & 8 & 5 & 50 & 18.10 & 18.40 \\
\hline 3 & 13 & 6 & 15 & 50 & 17.02 & 16.73 \\
\hline 4 & 11 & 8 & 15 & 50 & 19.01 & 19.42 \\
\hline 5 & 7 & 6 & 10 & 0 & 14.29 & 14.79 \\
\hline 6 & 8 & 8 & 10 & 0 & 16.74 & 16.53 \\
\hline 7 & 10 & 6 & 10 & 100 & 13.45 & 13.66 \\
\hline 8 & 9 & 8 & 10 & 100 & 17.66 & 17.16 \\
\hline 9 & 12 & 7 & 5 & 0 & 16.27 & 16.18 \\
\hline 10 & 4 & 7 & 15 & 0 & 15.45 & 15.25 \\
\hline 11 & 5 & 7 & 5 & 100 & 13.84 & 14.04 \\
\hline 12 & 15 & 7 & 15 & 100 & 16.80 & 16.89 \\
\hline 13 & 1 & 7 & 10 & 50 & 19.50 & 19.50 \\
\hline 14 & 14 & 7 & 10 & 50 & 19.50 & 19.50 \\
\hline 15 & 2 & 7 & 10 & 50 & 19.50 & 19.50 \\
\hline
\end{tabular}

Table 3 presents the proximate analysis of samples A, B and C. It can be seen that sample $\mathrm{B}$ had the highest percentage volatile solids, followed by sample $\mathrm{C}$, then sample A. The high percentage volatile solids of sample $\mathrm{B}$ can be attributed to high biodegradable materials in PW as a result of high intake of digestible materials [21]. The higher value of volatile solids in sample $\mathrm{C}$ compared to A can be attributed to proper mixing of the IPW and PW [22].

The $\mathrm{pH}$ values of samples $\mathrm{A}, \mathrm{B}$ and $\mathrm{C}$ were $6.0,8.8$ and 7.4 respectively. The $\mathrm{pH}$ value of sample $\mathrm{C}$ was adequate and within the limits required for biogas production [13]; while the $\mathrm{pH}$ values of samples A and B were inadequate and not within the limits for biogas production and there is the need for $\mathrm{pH}$ adjustment [21] The $\mathrm{pH}$ values of samples $\mathrm{A}$ and $\mathrm{B}$ are far from the optimum $\mathrm{pH}$ of biogas production of 7.0 but can be adjusted to make the wastes suitable for effective biogas production using sodium hydroxide $(\mathrm{NaOH})$ and hydrochloric acid $(\mathrm{HCl})$ respectively [6].

In addition, it can be seen from Table 4 that the $\mathrm{C} / \mathrm{N}$ ratios obtained for samples $\mathrm{A}$ and $\mathrm{C}$ were out of range of the standard ratio (20-30:1) for optimum biogas production [9]. On the other hand, the $\mathrm{C} / \mathrm{N}$ ratio for sample $\mathrm{B}$ fell within the range required for biogas production of 20-30:1 [9]. Therefore, $\mathrm{C} / \mathrm{N}$ ratio was not a limiting factor in sample $\mathrm{B}$. On the other hand, $\mathrm{C} / \mathrm{N}$ ratios were limiting factor to optimal biogas production in samples A and C [22]

\subsection{Optimization of biogas production}

The optimal levels for the independent variables and the effect of their interaction on biogas production were conducted in fifteen (15) experiments using the Box-Behnken design (BBD) of response surface methodology (RSM). Table 5 shows the experimental conditions (initial $\mathrm{pH}$ value, solids concentration and waste ratio) and the biogas yield (experimental and predicted) obtained from the process optimization of biogas production.

Table 5: Experimental Conditions and Biogas Yield

\begin{tabular}{|c|c|c|c|c|c|c|}
\hline \multirow[b]{2}{*}{$\mathrm{St}$} & \multirow[b]{2}{*}{$\mathrm{Ru}$} & \multicolumn{3}{|c|}{ Factor } & \multicolumn{2}{|c|}{ Biogas yield (Y) } \\
\hline & & A: & B: Solids & C: Waste & Experi- & \\
\hline
\end{tabular}

Table 5 shows the fifteen experimental runs sorted using standard order of the three factors (initial $\mathrm{pH} \mathrm{6-8,} \mathrm{solids} \mathrm{concentration} \mathrm{5-}$ $15 \%$ and waste ratio $0: 100$ to $100: 0 \%$ ) varied at three levels with their corresponding experimental and predicted biogas yields. The minimum and maximum values for experimental and predicted biogas yields were $13.45-19.50 \%$ and $13.66-19.50 \%$ respectively. [23] evaluated biogas yield of $17 \%$ from cow dung and watermelon peels which falls within the range of biogas yield in this present study.

The values obtained from the experimental design were subjected to response analysis to evaluate the relationship between initial $\mathrm{pH}$ (A), solids concentration (B) and waste mix ratio (C). By applying multiple regression analysis on the experimental data, the second order polynomial equation was derived to explain the biogas yield. Thus, the equation obtained based on mathematical regression models for biogas yield (Y) fitted in terms of actual factors is as follows.

Where; $\mathrm{A}, \mathrm{B}$ and $\mathrm{C}$ are initial $\mathrm{pH}$ value, solids concentration and waste ratio respectively.

The statistical significance of the second order polynomial equation was checked by Analysis of Variance (ANOVA), F-value and p-value as shown in Tables 6 and 7.
Table 6: Regression Model and Analysis of Variance (ANOVA)

\begin{tabular}{cccccc}
\hline Source & $\begin{array}{c}\text { Sum of } \\
\text { squares }\end{array}$ & df & $\begin{array}{c}\text { Mean } \\
\text { square }\end{array}$ & F-value & $\begin{array}{c}\text { p-value } \\
\text { Prob }> \\
\text { F }\end{array}$ \\
\hline $\begin{array}{cccccc}\text { Model } \\
\text { A-Initial pH } \\
\text { value }\end{array}$ & 56.59 & 9 & 6.29 & 26.27 & 0.0011 \\
& 13.76 & 1 & 13.76 & 57.46 & 0.0006 \\
\hline
\end{tabular}




\begin{tabular}{|c|c|c|c|c|c|}
\hline $\begin{array}{c}\text { B-Solids } \\
\text { concentration }\end{array}$ & 1.81 & 1 & 1.81 & 7.58 & 0.0402 \\
\hline C-Waste ratio & 0.13 & 1 & 0.13 & 0.52 & 0.5023 \\
\hline $\mathrm{AB}$ & $\begin{array}{c}5.625 \times 10- \\
3\end{array}$ & 1 & $5.625 \times 10-3$ & 0.023 & 0.8842 \\
\hline $\mathrm{AC}$ & 0.77 & 1 & 0.77 & 3.23 & 0.1320 \\
\hline $\mathrm{BC}$ & 3.57 & 1 & 3.57 & 14.92 & 0.0118 \\
\hline $\mathrm{A}^{2}$ & 3.54 & 1 & 3.54 & 14.78 & 0.0121 \\
\hline $\mathrm{B}^{2}$ & 3.15 & 1 & 3.15 & 13.16 & 0.0151 \\
\hline $\mathrm{C}^{2}$ & 32.93 & 1 & 32.93 & 137.55 & $\begin{array}{c}< \\
0.0001\end{array}$ \\
\hline Residual & 1.20 & 5 & 0.24 & & \\
\hline Lack of fit & 1.20 & 3 & 0.40 & & \\
\hline Pure error & 0.000 & 2 & 0.000 & & \\
\hline Cor total & 57.79 & 14 & & & \\
\hline \multicolumn{6}{|c|}{ Table 7: Model Fitness Summary } \\
\hline \multicolumn{5}{|c|}{ Parameter } & Value \\
\hline \multicolumn{5}{|c|}{ Std. dev. } & 0.49 \\
\hline \multicolumn{5}{|c|}{ Mean } & 16.89 \\
\hline \multicolumn{5}{|c|}{ C.V. $(\%)$} & 2.90 \\
\hline \multicolumn{5}{|c|}{ PRESS (predicted residual sum of squares) } & 19.15 \\
\hline \multicolumn{5}{|c|}{ R-squared (\%) } & 97.93 \\
\hline \multicolumn{5}{|c|}{ Adj R-squared (\%) } & 94.20 \\
\hline \multicolumn{5}{|c|}{ Pred R-squared (\%) } & 66.86 \\
\hline \multicolumn{5}{|c|}{ Adeq precision } & 14.622 \\
\hline
\end{tabular}

From Table 6, it can be seen that the F-value of 26.27 and p-value of 0.0011 implies the model is significant. The p-value represents the significance of the variables in which the smaller the p-value, the higher the significance of each variable. The p-value was less than 0.05 which indicated the model terms are significant. For biogas yield, the fit of the polynomial model was also expressed by the coefficient of determination $\left(\mathrm{R}^{2}\right)$ which was found as $97.93 \%$. The $\mathrm{R}^{2}$ value indicated a measure of variability in the observed response values which could be described by independent factors of the model. The linear model terms of initial $\mathrm{pH}$ value $(A)$ and solids concentration $(B)$ were significant $(p<0.05)$ and waste ratio $(C)$ was insignificant $(p>0.05)$. The interactive model terms for $A B$ and $A C$ were found to be insignificant $(p>0.05)$ and $\mathrm{BC}$ was significant $(\mathrm{p}<0.05)$. The quadratic model terms of $\mathrm{A}^{2}, \mathrm{~B}^{2}$ and $\mathrm{C}^{2}$ were significant $(\mathrm{p}<0.05)$ indicating that three variables had an individual effect on biogas yield.

It can be seen in Table 7 that the adequate precision (Adeq Precision) value of 14.622 indicated an adequate signal because it measures the signal to noise ratio and the ratio greater than 4 is desirable. This model can be used to navigate the design space. Here the adjusted coefficient of determination (Adj R-Squared) value of $94.20 \%$ was also very high, which indicate the higher significance of the model. The predicted coefficient of determination (Pred R-Squared) value of $66.86 \%$ indicates the poor agreement between the observed and predicted values. The difference between the Adj R-Squared and Pred R-Squared was $27.34 \%$ which should not be greater than $20 \%$, otherwise there may be a problem with either the data or the model [24]. The higher value of coefficient of variation (CV) gives lower reliability of the experiment but here a lower value of $2.90 \%$ indicated a high degree of precision and a good deal of reliability of the experimental values [25]. This model has high mean, low standard deviation and predicted residual sum of squares (PRESS) values of 16.89, 0.49 and 19.15 that were significant respectively.
Optimization was performed to investigate the optimum experimental conditions and biogas yield. It determines the optimum desirability depending on the "goals" set for each of the factors and response [26] \& [27]. In this study, the goal for initial $\mathrm{pH}$, solids concentration and waste ratio were set to "in range", whereas the goal for biogas yield was set to "maximize". The main reason why biogas yield was set to maximize was that the yield from a process needs to be maximum because it is the main product of the process. The desired goal of the model was to maximize biogas yield to achieve highest biogas production. The constraints were the experimental conditions and biogas yield for the model optimization as shown in Table 8 .

Table 8: Constraints for Experimental Conditions and Biogas Yield

\begin{tabular}{cccc}
\multicolumn{4}{c}{ Table 8: Constraints for Experimental Conditions and Biogas Yield } \\
\hline Name & Goal & $\begin{array}{c}\text { Lower } \\
\text { limit }\end{array}$ & Upper limit \\
\hline Initial $\mathrm{pH}$ value & in range & 6 & 8 \\
Solids & in range & 5 & 15 \\
concentration $(\%)$ & & & 100 \\
Waste ratio $(\%)$ & in range & 0 & 19.50 \\
Biogas yield $(\%)$ & maximize & 13.45 & \\
\hline
\end{tabular}

The verification experiment indicates that the maximum biogas yield was obtained when the values of each parameter were set as the optimum values as shown in Table 9. It implies that the strategy to optimize the experimental conditions and to obtain the maximum biogas yield using RSM for the biogas production in this study was successful at the highest desirability of 1.00.

Table 9: Optimum values for Experimental Conditions and Biogas Yield

\begin{tabular}{cccccl}
\hline $\begin{array}{c}\text { Solutions } \\
\text { number }\end{array}$ & $\begin{array}{c}\text { Initial } \\
\mathrm{pH} \\
\text { value }\end{array}$ & $\begin{array}{c}\text { Solids } \\
\text { concentration } \\
(\%)\end{array}$ & $\begin{array}{c}\text { Waste } \\
\text { ratio } \\
(\%)\end{array}$ & $\begin{array}{c}\text { Biogas } \\
\text { yield } \\
(\%)\end{array}$ & Desirability \\
\hline 1 & 7.28 & 9.85 & 45.47 & 19.7512 & 1.000 Se- \\
& & & & & lected \\
2 & 7.41 & 10.41 & 45.37 & 19.8672 & 1.000 \\
3 & 7.76 & 8.87 & 51.78 & 19.7669 & 1.000 \\
4 & 7.49 & 8.32 & 43.35 & 19.6136 & 1.000 \\
5 & 7.40 & 12.38 & 67.10 & 19.7133 & 1.000 \\
\hline
\end{tabular}

The verification experiment produced $19.85 \%$ of biogas yield at optimal conditions of initial $\mathrm{pH}$ value 7.28 , solids concentration (w/v) $9.85 \%$ and waste ratio (45.47\%) i.e. IPW:PW approximately (45:55\%) within 35 days' retention time. This also confirms that the biodegradation conditions which are initial $\mathrm{pH}$ value, solids concentration and waste ratio improved the anaerobic digestion process. The optimum initial $\mathrm{pH}$ value of 7.28 was close to the initial $\mathrm{pH}$ value of 7.11 obtained from the co-digestion of food waste and PW manure as reported by [13] \& [28]. Also, the optimum value of solids concentration of $9.85 \%$ closely agreed with the value of $10 \%$ obtained from food waste by [17]. The optimum value of waste ratio of 45:55 agreed with the equal blending of cow and elephant dungs in the ratio of $50: 50$ by [6]. In addition, the optimum biogas yield of $19.75 \%$ agreed with the biogas yield of $17 \%$ from cow dung and watermelon peels as reported by [23].

\subsection{Kinetics of Biogas Production}

Figures 1-3 shows the plots of zero, first and second order kinetic models of the experimental data respectively.

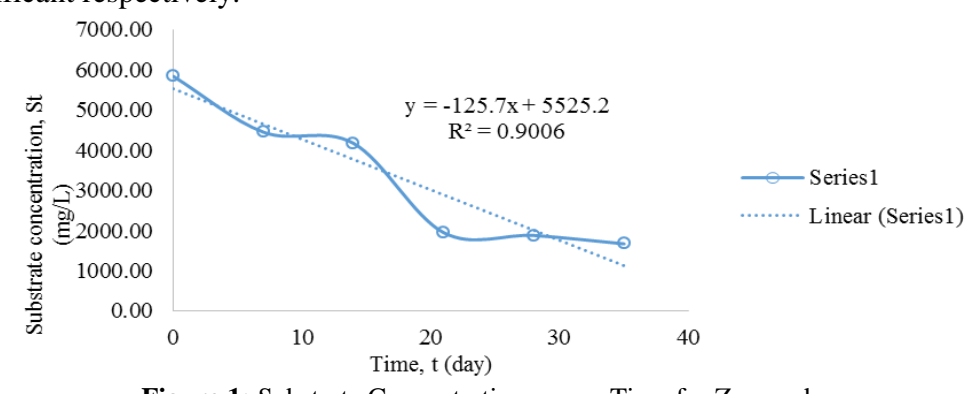

Figure 1: Substrate Concentration versus Time for Zero order 


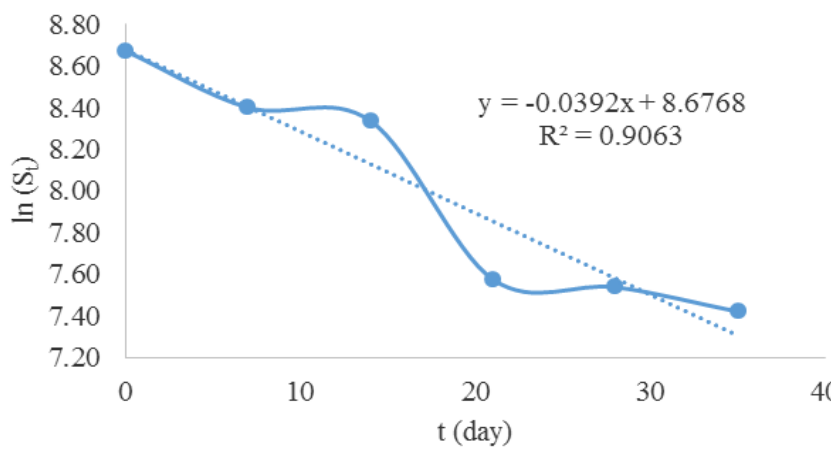

Figure 2: $\ln \left(\mathrm{S}_{\mathrm{t}}\right)$ versus Time for First order

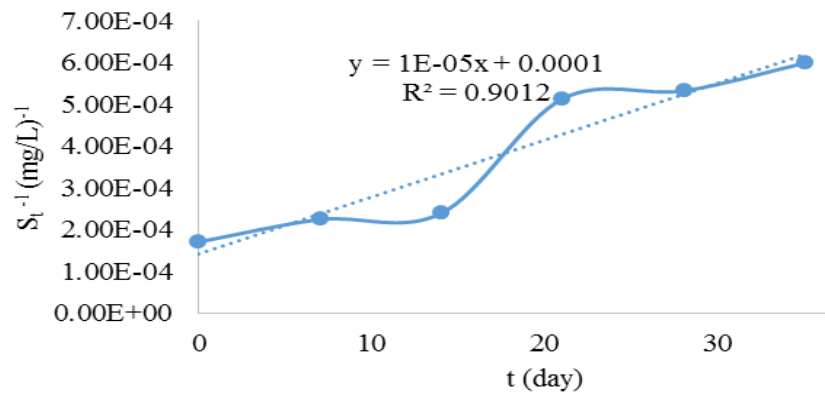

Figure 3: $\mathrm{S}_{\mathrm{t}}{ }^{-1}$ versus Time for Second order

From Figures 1-3 the developed models are thus:

$\mathrm{y}_{1}=-125.7 \mathrm{x}+5525.2$

(for zero order)

$\mathrm{y}_{2}=-0.0392 \mathrm{x}+8.6768$

(for first order)

$\mathrm{y}_{3}=0.00001 \mathrm{x}+0.0001$

(for second order)

Where; $\mathrm{y}_{1}$ is the predicted substrate concentration at time $\mathrm{t}\left(\mathrm{S}_{\mathrm{tp}}\right)$, $\mathrm{y}_{2}$ $=\ln \left(\mathrm{S}_{\mathrm{tp}}\right), \mathrm{y}_{3}=\mathrm{S}_{\mathrm{tp}^{-1}}$ and $\mathrm{x}=\mathrm{t}$. The kinetic parameters evaluated from the developed models are presented in Table 10.

Table 10: Evaluated Kinetic Parameters and Model Fitness Check

\begin{tabular}{|c|c|c|c|c|c|c|}
\hline \multirow[b]{2}{*}{$\begin{array}{c}\text { Kinetic } \\
\text { model }\end{array}$} & \multicolumn{2}{|c|}{ Rate constant (k) } & \multirow{2}{*}{$\begin{array}{l}\text { Half-life } \\
t_{1 / 2} \text { (day) }\end{array}$} & \multirow{2}{*}{$\begin{array}{c}\mathrm{S}_{\mathrm{o}} \\
\mathrm{mg} \cdot \mathrm{L}^{-1}\end{array}$} & \multirow{2}{*}{$\begin{array}{c}\mathrm{R}^{2} \\
(\%)\end{array}$} & \multirow{2}{*}{$\begin{array}{l}\text { RSE } \\
(\%)\end{array}$} \\
\hline & Value & Unit & & & & \\
\hline $\begin{array}{l}\text { Zero } \\
\text { order }\end{array}$ & 125.70 & $\begin{array}{l}\text { mg.L- } \\
{ }^{1} \text { day }^{-1}\end{array}$ & 21.98 & 5525.20 & 90.06 & 9.94 \\
\hline $\begin{array}{l}\text { First } \\
\text { order }\end{array}$ & 0.0393 & day $^{-1}$ & 17.68 & 5865.25 & 90.63 & 9.63 \\
\hline $\begin{array}{l}\text { Second } \\
\text { order }\end{array}$ & 0.00001 & $\begin{array}{l}\text { L.mg- } \\
{ }^{1} \text { day }^{-1}\end{array}$ & 10.00 & 10000.0 & 90.12 & 53.95 \\
\hline
\end{tabular}

Initial substrate concentration $\left(\mathrm{S}_{0}\right)$, coefficient of determination $\left(\mathrm{R}^{2}\right)$ and relative squared error (RSE)

The rate constant $(\mathrm{k})$ represents a measure of the wastes biodegradation rate and the half-life $\left(t_{1 / 2}\right)$ indicates the length of time it takes to degrade half the concentration of the organic wastes [29] $\&$ [30]. The higher the value of $\mathrm{k}$, the higher or faster is the rate of biodegradation and consequently the lower is the half-life of the waste for first order kinetic model [31] \& [32]. The zero, first and second order kinetic models were used to assess the dynamics of the biodegradation process and how close the models fitted the experimental data.

From Table 10, the biodegradation rate constant of $125.70 \mathrm{mg} . \mathrm{L}$ ${ }^{1}$.day $^{-1}$ and half-life of 21.98 days for the zero order model, indicated that at optimal conditions, $125.70 \mathrm{mg} . \mathrm{L}^{-1}$ of IPW and PW slurry per day degrades and it takes 21.98 days for the initial substrate concentration of $5525.20 \mathrm{mg} . \mathrm{L}^{-1}$ to reduce to half its value. Similarly, the first order model with biodegradation rate constant of 0.0392 day $^{-1}$ and half-life of 17.68 days, indicates that 0.0392 mg.L. $\mathrm{L}^{-1}$ of $1 \mathrm{mg} . \mathrm{L}^{-1}$ IPW and PW slurry per day degrade and it takes 17.68 days for the initial substrate concentration of 5865.25 $\mathrm{mg} . \mathrm{L}^{-1}$ to reduce to half its value. The same explanation applies to the second order model.

In addition, from the same table, the first order kinetic model gives the smallest RSE value of $9.63 \%$ and has the largest $R^{2}$ value of $90.63 \%$, which implies that the first order kinetic model describes the kinetic data best followed by the zero order and the least is theineac $Q$ Sictiosder. Most of the previous studies revealed that the substrate degradation and subsequent biogas production follows the first order kinetic [30] \& [33]. Therefore, in this study, the first order kinetic model can be used to describe the COD reduction from slurry of IPW and PW.

\section{Conclusions}

Optimization and kinetic of biogas production from the anaerobic degradation of two mixtures of wastes (IPW and PW) was investigated. Firstly, the characterization shows that the waste mixtures produced good substrate for biogas production; giving 63-74\% volatile solids and $21-36 \%$ carbon to nitrogen ratio. RSM was used to design Serjestodel the process, in which a predictive model was developed dioepre(diertithe) yield of the biogas production. The model had F-value of 26.27 and p-value of 0.0011 indicating that the model is significant. The fit of the polynomial model was expressed by the coefficient of determination of $97.93 \%$ which indicated a measure of variability in the observed response values described by independent factors of the model. Optimization outcome gave initial $\mathrm{pH}$ value of 7.28 , solids concentration of $9.85 \%$ and waste ratio (IPW:PW) of 45:55 with biogas yield of $19.75 \%$. In addition, the verification experiment produced $19.85 \%$ of biogas yield at the optimal conditions. Furthermore, the kinetic study revealed that first order kinetic model describes the biogas production best with rate constant and half-life of 0.0392 day $^{-1}$ and 17.68 days having coefficient of determination and relative squared error of 90.61 and $9.63 \%$ respectively. Therefore, the kinetic and optimization parameters obtained can be used to design a bio-digester, monitor the substrate concentration as reaction progresses and simulate the anaerobic digestion of IPW and PW.

\section{Acknowledgement}

The research funding by Tertiary Education Trust Fund (TETFUND), Nigeria through Abubakar Tafawa Balewa University, Bauchi, Nigeria is highly acknowledged.

\section{References}

[1] Ogwueleka, T. C., "Municipal Solid Waste Characteristics and Management in Nigeria", Iran Journal of Environmental Health Science and Engineering, Vol. 6, No. 3, (2009), pp. 173-180.

[2] Ngumah, C. C., Ogbulie, J. N., Orji, J. O., and Amadi, E. S., "Biogas Potential of Organic Waste in Nigeria", Journal of Urban and Environmental Engineering, Vol. 7, No. 1, (2013), pp. 110115 .

[3] Okareh, O. T., Oyewole, S. A. and Taiwo, L. B., "Conversion of Food Wastes to Organic Fertilizer: A Strategy for Promoting Food Security and Institutional Waste Management in Nigeria", Journal of Research in Environmental Science and Toxicology, Vol. 3, No. 4, (2014), pp. 68-73.

[4] Ezugwu, C. N., "Renewable Energy Resources in Nigeria: Sources, Problems and Prospects", Journal of Clean Energy Technologies, Vol. 3, No. 1, (2015), pp. 70-76.

[5] Yazidi, H., "Assessment of Ultimate Biogas Potential of CoDigested Fruits, Vegetables and Mixture of Fruits, Vegetables and Oil Substrates", International Journal of Core Engineering and Management, Vol. 2, No. 8, (2015), pp. 9-28.

[6] Abdulsalam, S. and Yusuf, M., "A Kinetic Study of Biogas Produced from Cow and Elephant Dungs Using the Residual Substrate Concentration Approach", Science and Education Publish- 
ing, Chemical Engineering and Science, Vol. 3, No. 1, (2015), pp. $7-11$.

[7] Wei, W., "Anaerobic Co-Digestion of Biomass for Methane Production", Recent Research Achievements, (2013), pp. 1-10.

[8] Khalil, M. J., Rimzhim, G. and Kartik, S., "Microbiological Degradation of Municipal Solid Waste in Landfills for Landfill Gas Generation", International Journal of Engineering and Technical Research, (2014), pp. 10-15.

[9] Oliveira, F. and Doelle, K., “Anaerobic Diestion of Food Waste to Produce Biogas: A Comparison of Bio-Digesters to Increase Methane Content: A Review", Journal of Food Processing and Technology, Vol. 6, No. 8, (2015), pp. 478-484.

[10] Saitawee, L., Hussaro, K., Teekasap, S. and Cheamsawat, N., "Biogas Production from Anaerobic Co-Digestion of Cow Dung and Organic Wastes (Napier Pak Chong and Food Waste) in Thailand: Temperature Effect on Biogas Product", American Journal of Environmental Science, Vol. 10, No. 2, (2014), pp. 129-139.

[11] Ahmed, S. I., Johari, A., Hashim, H., Alkali, H. and Ramli, M., "Economic and Environmental Benefits of Landfill Gas from Municipal Solid Waste in Malaysia", Renewable and Sustainable Energy Reviews, Vol. 16, (2012), pp. 2907-2912.

[12] Pannucharoenwong, N., "Optimization of Bio-Methane Production from Mesophilic Anaerobic Co-Digestion of Pig Manure and Vegetable Residue", International Journal of Applied Engineering Research, Vol. 13, No. 4, (2018), pp. 1988-1995.

[13] Yusof, T. R., Man, H. C., Rahman, N. A. and Hafid, H. S., “Optimization of Methane Gas Production from Co-Digestion of Food Waste and Poultry Manure Using Artificial Neural Network and Response Surface Methodology", Journal of Agricultural Science, Vol. 6, No. 7, (2014), pp. 27-37.

[14] Wauton, I. and Gumus, R. H., "Performance Evaluation of Reactor Types for the Mesophilic Anaerobic Digestion of Poultry Droppings", Journal of Environment, Vol. 2, No. 5, (2013), pp. 118-124.

[15] Ahmadian, M., Reshadat, S., Yousefi, N., Mirhossieni, S. H., Zare, M. R., Ghasemi, S. R. et al., "Municipal Leachate Treatment by Fenton Process: Effect of Some Variable and Kinetics", Journal of Environmental and Public Health, (2013), pp. 1-6.

[16] Kader, F., Baky, A. H., Khan, M. N. and Chowdhury, H. A., "Production of Biogas by Anaerobic Digestion of Food Waste and Process Simulation", American Journal of Mechanical Engineering, Vol. 3, No. 3, (2015), pp. 79-83.

[17] Thamilselvan, D., Kannan, M. and Lawrence, P., "Experimental and Theoretical Study on the Effect of Solid Concentration on Biogas Production from Food waste", International Journal of Advanced Engineering, Vol. 7, No. 2, (2016), pp. 1-3.

[18] Jyothilakshmi, R. and Prakash, S. V., "Design, Fabrication and Experimentation of a Small Scale Anaerobic Bio-Digester for Domestic Bio-Degradable Solid Waste with Energy Recovery and Sizing Calculations", Elsevier, Procedia Environmental Sciences, Vol. 35, (2016), pp. 749-755.

[19] Al-mamun, M. R. and Torii, S., "Production of Bio-Methane from Cafeteria, Vegetable and Fruit Wastes by Anaerobic Co-Digestion Process", Journal of Clean Energy Technologies, Vol. 3, No. 5, (2015), pp. 1-5.

[20] Aremu, M. O. and Agarry, S. E., "Comparison of Biogas Production from Cow Dung and Pig Dung under Mesophilic Condition", International Refereed Journal of Engineering and Science, Vol. 1, No. 4, (2012), pp. 1-6.

[21] Ibrahim, M. D., Ahmed, S. I, Musa, M. A., Isah, Y. M. and Garba, I., "Proximate and Ultimate Analyses of Some Selected Lignocellulosic Materials", Proceedings of the 6th Annual Conference of the Renewable and Alternative Energy Society of Nigeria 2016, University of Nigeria, Nsukka, (2016), pp. 1-8.

[22] Dioha, I. J., Ikeme, C. H., Nafi'u, T., Soba, N. I. and Yusuf, M. B. S., "Effect of Carbon to Nitrogen Ratio on Biogas Production", International Research Journal of Natural Sciences, Vol. 1, No. 3, (2013), pp. 1-10.

[23] Dahiru, U. H. and Abdulsalam, S., "Development of a Bench Scale Bio-Digester for the Production of Bio-Fertilizer Using Cow Dung and Watermelon Peels", Chemical and Process Engineering Research, Vol. 47, (2017), pp. 1-11.

[24] Chanabasayya, D. and Vastrad, M., "Performance Analysis of Neural Network Models for Oxazolines and Oxazoles Derivatives Descriptor Dataset", International Journal of Information Sciences and Techniques, Vol. 3, No. 6, (2013), pp. 1-15.

[25] Dyartanti, E. R., Susanto, H., Widiasa, I. N. and Purwanto, A., "Response Surface Method (RSM) for Optimization of Ionic
Conductivity of Membranes Polymer Electrolyte Poly (Vinylidene Fluoride) (PVDF) with Polyvinyl Pyrrolidone (PVP) as Pore Forming Agent", IOP Publishing, 29th Symposium of Malaysian Chemical Engineers 2016, (2017), pp. 1-13.

[26] Chan, J. S., Ghadimi, A., Metselaar, H. S. C. and Lotfizadehdehkordi, B., "Optimization of Temperature and Velocity on Heat Transfer Enhancement of Non-Aqueous Alumina NanoFluid", Journal of Engineering Science and Technology, (2015), pp. 85-101

[27] Dutta, S., Ghosh, A., Moi, S. C. and Saha, R., "Application of Response Surface Methodology for Optimization of Reactive Azo Dye Degradation Process by Fenton's Oxidation", International Journal of Environmental Science and Development, Vol. 6, No. 11, (2015), pp. 818-823.

[28] Paramaguru, G., Kannan, M. and Lawrence, P., "Effect of pH on Biogas Production through Anaerobic Digestion of Food Waste", Journal of Advanced Engineering Research, Vol. 4, No. 1, (2017), pp. 59-62.

[29] Dadrasnia, A. and Ismail, S. B., "Bio-Enrichment of Waste Crude Oil Polluted Soil: Amended with Bacillus 139SI and Organic Waste", International Journal of Environmental Science and Development, Vol. 6, No. 4, (2015), pp. 241-245.

[30] Abu-Reesh, I. M., "Kinetics of Anaerobic Digestion of Labaneh Whey in a Batch Reactor", African Journal of Biotechnology, Vol. 13, No. 16, (2014), pp. 1-11.

[31] Ali, A. H., Abdulrazaq, Z., Tlaiaa, Y. and Khishala, A. D., "Methane Biogas Production from Mixing of Algae and Municipal Solid Waste by Anaerobic Digestion", International Journal of Environmental Resources, Vol. 10, No. 4, (2016), pp. 613-624.

[32] Yavini, T. D., Silas K., Grema, M. B. and Luria, J. A., "Kinetic Study of Agricultural Wastes Conversion to Biogas Using Cow Dung/Poultry Droppings as Inoculums", Journal of Environmental Science, Toxicology and Food Technology, Vol. 8, No. 1, (2014), pp. 46-51.

[33] Akpoveta, O. V., Egharevba, F. and Medjor, O. W., "A Pilot Study on the Bio-Degradation of Hydrocarbon and its Kinetics on Kerosene Simulated Soil", International Journal of Environmental Sciences, Vol. 2, No. 1, (2011), pp. 54-6. 